\title{
개발원조위원회 회의결과
}

\section{| . 핵심요지}

$\square$ 개발원조위원회 정기회의가 9.20 21간 개최되어 향후 원조규모 확대계획에 수반되는 이슈인 원조 의 배분 및 원조의 효과성 제고방안, 원조의 언타 이드화, 개도국의 능력개발 문제 등을 논의한 바, 향후 개발원조에 관한 국제사회의 논의는 원조의 효과성 제고를 위한 구체적인 실천계획에 초점이 모아질 것으로 전망됨.

$\square$ 우리나라도 금년 유엔정상회의시 2009년까지 GNI 대비 ODA 비율을 0.1\%로 확대한다는 비젼을 제시하였으나, 이러한 우리의 ODA 확대계획이 제 대로 평가받기 위해서는 DAC 가입계획, 예측가능 한 원조 제공 차원에서 연도별 ODA 확대계획, 국 가별 원조배분 중기계획, 원조의 효과성 제고 방안 (원조의 언타이드화 포함) 및 독립적인 평가시스템 등을 조기에 수립할 필요가 있다고 판단됨.
II. 세부 논의결과

1 원조규모 확대 및 배분문제

$\square$ 세계은행(WB) 개발위원회 9월 정기회의 계기에 $\mathrm{DAC}$ 회원국(지역개발은행 포함) 장관급회의를 9. 26(월) 워싱턴에서 개최하여 향후 원조규모 확대 구체방안 및 확대되는 원조의 배분, 효과성 제고 방안에 대하여 논의하기로 합의함.

- 지금까지 공여국들이 천명한 원조확대계획 관 련 구체적인 내용, 년도별 원조규모, 구체적인 배분(allocation)에 관한 방법론 등에 대하여 논 의 예정

- 동 회의는 WB와 DAC가 공동주최하며, Manning DAC 의장 및 Leipziger 세계은행 부 총재가 공동의장으로 주재 예정

$\square$ 금년 DAC SLM 회의(12. 6- 7)에서도 향후 원조규 모 확대에 따른 제반 사항을 논의하기로 합의함.

- 앞으로 개도국별로 원조자문그룹회의 개최시 
개도국들은 향후 자국이 받게 될 원조규모 및 원조채널에 대하여 많은 관심을 갖게 될 것이 며, 파리선언문에서 합의한 예측가능한 원조 제 공 차원에서 공여국은 대략적인 사항을 알려줄 책임이 따르게 됨.

- 이와 관련, 대다수 국가들은 원조규모 확대를 공약하였음에도 불구하고, 현재로서는 3년(또는 1년) 이상의 구체적 계획을 발표하는데는 어려 움이 있다는 입장을 표명함.

2. 금년도 DAC SLM 의제

실질의제로는 ODA 확대 관련사항으로서 ODA 배분, 원조효과 모니터링, 개도국의 능력개발, 경 제성장과 빈곤감축, 원조의 untying 확대방안 등 을 논의하며,

$\square$ 오찬의제로는 쓰나미 1주년을 계기로 공여국의 원 조공약 및 실제 지출 분석, 성과 및 여론 동향을 논 의하며,

$\square$ Housekeeping 이슈로는 2007 8년도 작업우선 순위, 자발적 기여금에 관하여 논의하기로 합의함.

3. DAC 수원국 리스트 개정

$\square$ 기존의 DAC 수원국 리스트는 Part I 및 Part II 국가로 구분하였으나, 이를 구분하지 않고 단일 수원국 리스트로 개정한다는 원칙에 합의함. 또한 G8 회원국 및 EU 회원국은 수원국 리스트에서 제 외시키고(불가리아, 루마니아는 2007년 EU 가입 시 졸업), 매3년마다 재검토한다는데 의견접근이 이루어졌으나, 기존에 Part II 국가인 벨라루스,
리비아, 우크라이나를 단일 수원국 리스트에 추가 하는 문제, 사우디아라비아(1인당 소득 10,430불) 가 고소득국으로 분류되어 당장 졸업시키는 문제 에 대한 이견으로 인해 추후 재검토키로 함.

- 2006년부터 발효(2005년도 ODA 통계부터 적 용)를 위해 금년도 SLM 회의시 타결을 목표로 하여 이견이 있는 국가를 대상으로 별도로 소규 모그룹회의를 소집키로 합의

\section{4. 원조의 언타이드화 노력}

$\square$ 파리선언문에서 합의한 원조효과 증진 차원에서 언타이드 원조의 비율을 높이기 위해 2001년 $\mathrm{DAC}$ 권고문을 재검토한 바,

- 2001년 언타이드 원조 권고문을 적용할 국가를 현재 최빈국그룹에서 저소득국그룹으로 확대하 는 방안이 경우 언타이드 원조 규모가 15억불 증가 예상)을 우선 검토하고(원조의존율에 따른 적용대상 확대문제는 차선의 대안으로 검토),

- 독립적 기술협력(FTC)에 대해서도 2001년 권고 문을 적용하는 문제는 원조통계작업반의 논의 결 과가 나온 후에 결정하며, 타이드 원조 여부에 관 한 정의를 개정하지 않으면서 회원국의 노력을 인정하는 방법으로 현지구매를 촉진하는 방안을 모색한다는 것에는 대체로 의견접근이 이루어짐. $\square$ 그러나 2005년 12월 SLM에 상정할 조기타결 방 안으로서 권고문 적용 여부와 관련이 있는 액수 기준(70만 SDR)을 철폐하는 방안(이 경우 언타이 드 원조 규모 10 억불 증가) 및 조달과 밀접한 관련 이 있는 일부 기술협력에 대하여 untying하는 방 
안에 대해서는 회원국간 이견으로 추가 논의키로 함(2001년도 권고문에 의하면, 독립적 기술협력은 언타이드 대상에서 제외).

$\square$ 식량원조 및 긴급원조는 미국 등 일부 국가의 강 력한 반대, 신속지원 필요성 등을 감안 untying을 추진하지 않는다는데 대체로 합의함.

5. 개도국의 무역을 위한 원조(Aid for Trade)에 관한 DAC 특별회의

$\square$ 금년 12월 WTO 홍콩각료회의 측면지원 및 동 회 의 개최 이후까지 준비한다는 차원에서 오는 10. 27 개도국 무역을 위한 원조에 관한 DAC 특별회 의를 개최한다는데 합의함.

$\square$ 논의 의제는 개도국의 무역을 위한 원조의 효과 증 진 방안, 무역을 위한 기존의 원조 제공 메카니즘 의 효과성을 개선하는 방안, 무역을 위한 원조작업 과 빈곤감축 과제간의 시너지 제공방안 등을 중점 의제로 함.

6. 능력개발 모범사례 paper

$\square \mathrm{DAC}$ 산하 거버넌스네트워크(GOVNET)가 준비 중인 능력개발 모범시례 paper를 검토한 바, 동 paper가 개도국의 능력개발에 관한 문제점을 정 확하게 지적하고, 올바른 접근법을 제시하고 있으 며, 금년내에 문서를 완성하여 채택해야 한다는데 대체로 의견이 일치함.

- 대다수 빈곤국들은 현 상태로는 공여국으로부 터 경제원조가 확대되더라도 지속가능한 능력 개발이 되어 있지 않아 실패하게 되어 있음.
- 능력개발은 개인의 능력과 기술을 향상시키는 것뿐만 아니라 기관의 능력 개발, 그리고 제도 및 관리체제(rules of the game)를 포함하는 포 괄적인 것으로 이해해야 하며, 종합적인 접근이 요망됨.

- 국제사회는 최근까지도 능력개발을 지식이나 조직모델을 전수하는 기술적인 것으로 간주하 여 국가적 특수상황에 대한 고려가 부족하였음. - 2005년 파리선언에서 개도국의 능력개발은 개 도국이 1차적 책임을 지고 개도국 내부에서 발 생해야 하고, 공여국은 보조적 역할을 해야 한 다고 합의함.

$\square$ 그러나, 개도국이 능력개발에 관한 ownership이 미약한 경우 그리고 개도국의 능력개발에 관한 요 청을 공여국의 전문가적 시각에서 수용이 곤란한 경우는 흔히 발생하는 상황이므로 이에 대한 보완 이 필요하며, 개도국의 brain drain 현상은 개도 국의 능력개발과 깊은 관련성이 있으므로 이를 심 도있게 검토해야 한다는 점이 지적됨.

7. DAC 동료심사에 대한 옵서버 참여 문제

$\square$ 옵서버의 범위에 대하여 OECD Non- DAC 회원국 으로 한정해야 한다는 입장 및 여타 신흥공여국 및 개도국에게 문호를 개방해야 한다는 입장이대립됨.

$\square$ 또한 peer review 전과정중 field mission 참가 허용 여부 및 동 경비부담 문제에 대해서도 의견 의 일치를 보지 못하여 추가 검토키로 함.

[자료 : 주오이시디 대표부] 